\title{
NA-NA, NA-NA, BOO-BOO, THE ACCURACY OF YOUR PHILOSOPHICAL BELIEFS IS DOO-DOO
}

\author{
MARK WALKER \\ https://orcid.org/0000-0001-5835-3296 \\ New Mexico State University \\ Department of Philosophy \\ Las Cruces, New Mexico \\ U.S.A. \\ mwalker@nmsu.edu
}

\section{Article info}

CDD: 501

Received: 22.04.2021; Revised: 12.07.2021; Accepted: 08.12.2021

https://doi.org/10.1590/0100-6045.2022.V45N1.MW

\section{Keywords}

Accuracy

Skeptical-Dogmatism

Abstract: The paper argues that adopting a form of skepticism, Skeptical-Dogmatism, that recommends disbelieving each philosophical position in many multi-proposition disputesdisputes where there are three or more contrary philosophical views-leads to a higher ratio of true to false beliefs than the ratio of the "average philosopher" (as indicated by survey data). Hence, Skeptical-Dogmatists have more accurate beliefs than the average philosopher. As a corollary, most philosophers would improve the accuracy of their beliefs if they adopted Skeptical-Dogmatism.

\section{Introductory}

...both for Socrates and all his successors, this is what being a philosopher and living a philosophical life meant: living according to reason, conceived as a 
capacity for argument and analysis in pursuit of the truth.

-John Cooper ${ }^{1}$

The Cruel God of Epistemology is appalled that human philosophers have ignored their Socratic heritage: many philosophers today seem indifferent or even hostile to the question of the accuracy of their philosophical beliefs. She has chosen you as the "lucky" one tasked with rectifying this situation. You have been given an app for your phone that sets philosophers' beliefs. ${ }^{2}$ For a number of important philosophical controversies, there are sliders on the app with the following settings: $\mathrm{B}=$ "believe $\mathrm{P}$ (or at least believe $\mathrm{P}$ is more likely true than not)", $\mathrm{S}=$ "suspend judgement about $\mathrm{P}$ ", and $\mathrm{D}=$ "disbelieve $\mathrm{P}$ (or at least believe $\mathrm{P}$ is more likely false than not)". So, for example, for the dispute about the "big three" in normative ethics-deontology, consequentialism, and virtue ethics - the app allows you to choose $\mathrm{B}, \mathrm{S}$, or $\mathrm{D}$ for philosophers. The app also shows what philosophers currently believe about these disputes. ${ }^{3}$

To incentivize cooperation, the Cruel God threatens that she will destroy humanity if you fail to improve philosophers' doxastic average accuracy. You think to yourself, "Refusing to cooperate is not an option, since annihilation will ensue. Philosophy is difficult, and I could

${ }^{1}$ John M. Cooper, "Socrates and Philosophy as a Way of Life," Maieusis: Essays in Ancient Philosophy in Honour of Myles Burnyeat, 2007, 20-43. At 23.

2 The Cruel God also adds the stipulation that Egalitarianism is true. This won't make sense until the following section.

3 The app uses data from a survey on philosophical belief: David Bourget and David J. Chalmers, "What Do Philosophers Believe?," Philosophical Studies 170, no. 3 (2014): 465-500.

Manuscrito - Rev. Int. Fil. Campinas, v. 45, n. 2, pp. 1-49, Apr.-Jun. 2022. 
be wrong about a lot of my philosophical views. Surely, however, using what I know about philosophical disputes is better than guessing or flipping a coin to decide." So, you opt to complete the task using the knowledge that you've gained in more than twenty years studying philosophy. As you enter your responses into the app from the survey you took a few years ago, you realize how stable your philosophical beliefs are. Although you are not so epistemically hubristic as to think you are infallible, nevertheless, your survey response, "lean towards deontology", seems as right today as it did when you completed the survey several years ago. So, you set all philosophers to "believe deontology is true, or at least more likely true than not" on your app. (You justify this violation of the epistemic autonomy of so many philosophers in terms of the horrendous consequences of not doing so.) You scroll through the disagreements listed on the app and dial in philosophers' beliefs to agree with you about those issues you have thought long and hard about. After pressing "submit" you wait apprehensively. The Cruel God studies the results for a few seconds and then laughs: the average accuracy of philosophers' beliefs has declined.

Seeing the horrified look on your face she says (feigning a little compassion) that you have nothing to be embarrassed about: your accuracy is only slightly less than that of the average philosopher. She adds that if you had only put aside your pretensions to greater accuracy than the average philosopher and used some elementary probabilistic reasoning of the sort that a competent undergraduate could easily understand, then you could have saved humankind. But, alas, the hubris that you share with so many other philosophers interfered with clear thinking. At which point, the Cruel God smites humanity.

Despite her cruel ways, the Cruel God is correct: a little elementary probabilistic reasoning shows that if one is a 
certain sort of skeptic in many philosophical disputes, then one can be assured that one's beliefs are more accurate than the average philosopher. ${ }^{4}$ At least, so I shall argue. If my thesis is correct, then improving the accuracy of philosophers' belief is — at least in theory — straightforward: if all philosophers become skeptics (of a certain sort), then the average accuracy of philosophers' beliefs will increase.

\section{Doxastic Accuracy}

The term 'accuracy' is a new name for a very old idea: the epistemic attitudes of individuals vary in terms of the preponderance of true to false beliefs. ${ }^{5}$ It is generally assumed, other things being equal, that true belief is better than false belief. But, at least for present purposes, the normative question of the value of accuracy should be treated independently of the question of the extent to which our beliefs are accurate. For example, it is often observed that an inaccurate belief may be prudentially or morally valuable, which raises the question of the relative weight we ought to give to accuracy in such situations. For immediate purposes, we may think of giving an account of accuracy as answering a descriptive question about how close or far an

${ }^{4}$ I leave for another day whether the same line of argument applies to other areas of inquiry, like religion and science.

${ }^{5}$ I suspect the argument could be translated to talk in terms of credence in a straightforward manner. For a credal treatment of accuracy, see Richard Pettigrew, Accuracy and the Laws of Credence (Oxford University Press, 2016). For the belief model, see Kenny Easwaran and Branden Fitelson, "Accuracy, Coherence, and Evidence," Oxford Studies in Epistemology 5 (2015): 61-96. And Kevin Dorst, "Lockeans Maximize Expected Accuracy," Mind 128, no. 509 (2019): 175-211.

Manuscrito - Rev. Int. Fil. Campinas, v. 45, n. 2, pp. 1-49, Apr.-Jun. 2022. 
agent's belief set is from the truth. Unless otherwise noted, when talking about the relative value of truth and falsity, this should be understood in terms of increasing accuracy or inaccuracy, and neutral on the question of the value of accuracy vis-à-vis prudential, moral or non-accuracy epistemic reasons for holding our beliefs. The final section will offer some (brief) reflection on the value of accuracy of our philosophical beliefs.

Some assessments of accuracy are easy: a perfectly accurate believer is one whose belief set maximally comprises all and only true beliefs. A paradigmatic example here is an omniscient being. Conversely, a perfectly inaccurate doxastic agent is one whose belief set maximally comprises all and only false beliefs. A paradigmatic example here is an academic administrator. Questions about doxastic accuracy quickly get more difficult when thinking about cases of mixed true and false beliefs. For example, we may puzzle over the relative accuracy of S1's and S2's belief sets about some specific domain of inquiry:

S1: S1 has 10 true beliefs and no false beliefs.

S2: S2 has 11 true beliefs and 1 false belief.

How much does the false belief take away from the accuracy of S2's beliefs as compared with S1's?

To sort through this, it will help to make a few distinctions. Let us understand "getting it right" (R) to mean believing $\mathrm{P}$ when $\mathrm{P}$ is true, and disbelieving $\mathrm{P}$ when $\mathrm{P}$ is false. Contrariwise, "getting it wrong" (-W) means believing $\mathrm{P}$ when $\mathrm{P}$ is false, and disbelieving $\mathrm{P}$ when $\mathrm{P}$ is true. So, in terms of measuring accuracy, believing $\mathrm{P}$ when $\mathrm{P}$ is true adds as much to accuracy as disbelieving $\mathrm{P}$ when $\mathrm{P}$ is false. Similarly, believing $\mathrm{P}$ when $\mathrm{P}$ is false reduces accuracy as much as disbelieving $\mathrm{P}$ when $\mathrm{P}$ is true. We also need to add an additional category here: suspending belief about $\mathrm{P}$ means 
being agnostic about $\mathrm{P}$, neither believing $\mathrm{P}$ is more likely than $\mathrm{P}$, nor not-P more likely than P. ${ }^{6}$ Whether $\mathrm{P}$ is true or false, suspension of belief about $P$ neither adds nor subtracts to/from the overall accuracy of a belief set. ${ }^{7}$

One way to parse the question about the relative accuracy of S1 and S2 is to ask how much value should be attributed to S1's avoidance of error, not getting it wrong, (hereafter 'W') in comparison to S2 having a higher $\mathrm{R}$ value. There are three possibilities:

\section{Incautiousness: $\mathrm{R}>\mathrm{W}$ \\ Egalitarianism: $\mathrm{R}=\mathrm{W}$ \\ Cautiousness: $\mathrm{W}>\mathrm{R}^{8}$}

So, if Incautiousness is correct, then S2's views are more accurate than S1's because the additional value of an extra true belief is not offset by the loss of value of having a false belief. If Egalitarianism is true, then S1's and S2's belief sets are equally accurate because the added value of having an additional true belief is exactly offset by the disvalue of

${ }^{6}$ There are a number of complications about suspended judgement that I shall pass over here, as it does not ultimately play a large role in the argument. For some of these complications, see Jane Friedman, "Suspended Judgment," Philosophical Studies 162, no. 2 (2013): 165-81. Michal Masny, "Friedman on Suspended Judgment," Synthese, 2018, 1-18.

7 See Florian Steinberger, "Accuracy and Epistemic Conservatism," Analysis 79, no. 4 (2019): 658-69. Dorst, "Lockeans Maximize Expected Accuracy."

${ }^{8}$ I follow several others in this exposition of three possibilities for accuracy, including Richard Pettigrew, "Jamesian Epistemology Formalised: An Explication of "The Will to Believe," Episteme 13, no. 3 (2016): 253-68. Steinberger, "Accuracy and Epistemic Conservatism." 
having a false belief. Finally, if Cautiousness is correct, then S1's belief set is more accurate than S2's because the disvalue of having a false belief is greater than the added value of an additional true belief.

There appears to be powerful reasons to think Cautiousness is the most plausible measure of accuracy. ${ }^{9}$ To see why, let us start by thinking about the category of suspension of belief in connection with Egalitarianism, using the following numerical assignments to illustrate:

Egalitarianism Numerical Assignment: $\mathrm{R}=1.0$, $\mathrm{SB}=0.0$, and $-\mathrm{W}=-1.0$

Suppose you and I watch a series of 100 coin flips. I confidently form beliefs about whether the coin will land heads or tails each time, while you suspend belief. My beliefs are correct half the time-I consistently overrate my ability to predict the coin flip. Egalitarianism says that our beliefs are equally accurate. I expect that many will agree that in terms of accuracy, my beliefs should rank lower than yours. This suggests that Egalitarianism gets it wrong as a measure of accuracy. Similarly, suppose I have two inconsistent beliefs: (i) I believe the coin will land heads. (ii) I believe the coin will land tails. Here I will be right 100 times and wrong 100 times. ${ }^{10}$ Again, this yields the same net accuracy, according to Egalitarianism, for both you and me. But surely

9 Dorst, "Lockeans Maximize Expected Accuracy." Steinberger, "Accuracy and Epistemic Conservatism."

10 The argument about contradictory beliefs is sensitive to assumptions about how to individuate beliefs. The argument depends on the assumption that S's belief that $\mathrm{P}$, and S's belief that not-P, are to be counted individually for purposes of accuracy scoring. Thanks to an anonymous reviewer for pressing this point. 
there is something to be said for the greater accuracy of your beliefs. ${ }^{11}$

The same examples show how implausible Incautiousness is. Let us assume the following very modest numerical assignments for Incautiousness:

Incautiousness Numerical Assignment: $\mathrm{R}=1.0$, $\mathrm{SB}=0.0$, and $-\mathrm{W}=-0.9$

The numerical assignments are modest in the sense that -W $+\mathrm{R}$ is only slightly more than the value of $\mathrm{SB}$. In the guessing version, Incautiousness says that my beliefs are more accurate than yours. Your net accuracy in the coin flipping case is still 0.0. My net accuracy is $5 .{ }^{12}$ In the version where I have beliefs that are inconsistent, your net accuracy remains 0.0 while my net accuracy is $10 .{ }^{13}$

Cautiousness fares much better with these examples. Let us assume the following modest numerical assignments for Cautiousness:

Cautiousness Numerical Assignment: $\mathrm{R}=1.0, \mathrm{SB}$ $=0.0$, and $\mathrm{W}=-1.1$

Again, the numerical assignments are modest in the sense that the value of $-\mathrm{W}+\mathrm{R}$ is only slightly less than the value of SB. In the guessing version, Cautiousness says that my beliefs are less accurate than yours. Your net accuracy is still 0.0 , while my net accuracy is $-5 .{ }^{14}$ In the version where I have

${ }^{11}$ For more on these sorts of examples, see Dorst, "Lockeans Maximize Expected Accuracy."

${ }^{12}(50 \times 1)+(50 \times-0.9)=5$.

$13(100 \times 1)+(100 \times-0.9)=10$.

$14(50 \times 1)+(50 \times-1.1)=-5$. 
two inconsistent beliefs, your net accuracy remains 0.0 , while my net accuracy is $-10 .{ }^{15}$

So, while it seems there are powerful reasons to favor Cautiousness, I will not attempt to adjudicate the issue here. I shall assume (without further argument) that Incautiousness is not worthy of our allegiance, and so I will focus on Cautiousness and Egalitarianism in what follows.

\section{Pyrrhonians and Improved Accuracy}

In this section, we will look at perhaps the most familiar form of doxastic skepticism: Pyrrhonism. In later sections we will examine a "darker" form of skepticism. Here I hope to show that under certain circumstances, adopting the Pyrrhonian position of suspending belief has potential for improving the accuracy of philosophical belief, but the case for Pyrrhonism requires Incautiousness. In latter sections I hope to show there is little "real world" applicability for a guarantee of higher accuracy using this strategy.

Think of a 'balanced dispute' as one where there are equal numbers of philosophers holding opposing positions, and a binary dispute where one party believes "P" and the other "not-P". To calculate the average accuracy in a balanced binary dispute, let us suppose 50 Stoics believe in divine providence, and 50 Epicureans disbelieve in divine providence. Interestingly, we do not need to determine which side is correct in the dispute to ascertain their average. Using the previous numerical assignments for Cautiousness, we get an accuracy rating for the 100 philosophers of $-5.0,{ }^{16}$ and so an average accuracy of -0.05 .

${ }^{15}(100 \times 1)+(100 \times-1.1)=-10$.
${ }^{16}(50 \times 1)+(50 \times-1.1)=-5.0$

Manuscrito - Rev. Int. Fil. Campinas, v. 45, n. 2, pp. 1-49, Apr.-Jun. 2022. 
Pyrrhonists, of course, suspend judgement on the question of divine providence ${ }^{17}$, so Pyrrhonists have an average accuracy of 0.0 - higher than the non-Pyrrhonian philosophers. If the 50 Stoics and the 50 Epicureans could be persuaded to become Pyrrhonists, then the average accuracy of the 100 philosophers would increase to 0.0. So, under these conditions, if all philosophers were more skeptical (in the Pyrrhonian sense), then the average accuracy of their doxastic attitudes would increase.

As intimated above, Pyrrhonism offers a higher average accuracy only on the assumption that Cautiousness is true. If Egalitarianism is true, then the average of the 50 Stoics and Epicureans is 0.0, not -0.05 .

A balanced (or nearly balanced) dispute is also necessary to guarantee higher accuracy. For example, suppose the number of philosophers on each side of the dispute is slightly out of balance: 55 Stoic philosophers get it right and 45 Epicureans get it wrong. The net accuracy using Cautiousness is $5.5^{18}$, with an average accuracy of 0.05 . This is of course better than the Pyrrhonian average of 0.0 . So, if the Stoics and Epicureans were all persuaded of Pyrrhonism, then given present assumptions, their average accuracy would fall. Of course, if the majority had the wrong view, then things would swing back in favor of the Pyrrhonians. What this shows is that Pyrrhonians may have higher accuracy in an unbalanced dispute, but they can be guaranteed higher accuracy only in a balanced binary dispute. ${ }^{19}$

17 Indeed, divine providence is an example drawn from Sextus Empiricus, "Outlines of Pyrrhonism," in The Skeptic Way, translated by Benson Mates (New York: Oxford University Press, 1996).

$18(55 \times 1)+(45 \times-1.1)=5.5$.

19 This is based on the assumption of a moderate version of Cautiousness. As we shall see in the penultimate section, things 


\section{Skepticism, Skeptical-Dogmatism, and Dogmatism}

To extend the argument, we need to do two things: (i) clarify different types of skeptical and anti-skeptical responses to philosophical disputes, and (ii) examine the logic of philosophical disputes.

As we shall use the term, 'Dogmatists' about P hold that $\mathrm{P}$ is true, or that $\mathrm{P}$ is at least more likely true than not. In Bayesian terms, this may be cashed-out as a credence of greater than 0.5 that P. In terms of belief talk, the belief, "it will rain tomorrow" counts as Dogmatism. The modally modified propositions, e.g., "it will probably rain tomorrow", when believed, also count as Dogmatic in our sense. Even the belief in something as weak as, "it is slightly more likely than not that it will rain tomorrow" or "leaning towards P" counts as Dogmatism.

Understanding Dogmatism in this way is helpful, since it permits us to acknowledge that philosophers have a range of doxastic attitudes to their preferred philosophical views. A survey of philosophical beliefs indicates that many philosophers "accept" or "lean towards" a wide variety of positions within disputed areas of philosophy. ${ }^{20}$ Indeed, more philosophers adopt the more tentative "lean towards" category than "accept" for most philosophical views canvassed. For example, the normative ethics question breaks down as follows:

improve considerably for the Pyrrhonian if "Super Extreme Cautiousness" is plausible.

${ }^{20}$ Bourget and Chalmers, "What Do Philosophers Believe?" 
Table 1: Data from Normative Ethics Question Posed By Bourget And Chalmers

\begin{tabular}{|l|l|l|l|}
\hline & Lean Towards & Accept & Total \\
\hline Deontology & $16.0 \%$ & $9.9 \%$ & $25.9 \%$ \\
\hline Consequentialism & $14.0 \%$ & $9.7 \%$ & $23.7 \%$ \\
\hline Virtue Ethics & $12.6 \%$ & $5.6 \%$ & $18.2 \%$ \\
\hline Total & $42.6 \%$ & $25.2 \%$ & $67.8 \%{ }^{21}$ \\
\hline
\end{tabular}

Thus, $63 \%$ of respondents in these three categories "lean towards" their preferred views, while only 37\% "accept" their positions. So, the more epistemically modest position, "lean towards" enjoys a nearly 2 to 1 advantage. However, as indicated above, both the "lean towards" and "accept" categories count as Dogmatism as we understand the term. As a crude translation, we will think of the survey response of "accept" as "believe that P", and the "lean towards P" response as "believe that $\mathrm{P}$ is at least more probable than not." Unless otherwise noted, I will use 'believe' to mean both outright belief in $\mathrm{P}$, and the more modest position of believing that $\mathrm{P}$ is more probable than not.

We will understand 'Skepticism' somewhat analogous to the Pyrrhonian sense outlined above: the Skeptic suspends judgement as to the truth of $\mathrm{P}$. In credence talk, this means the Skeptic has no more credence in P than in not-P. In belief talk, this amounts to the claim that the Skeptic does not believe $\mathrm{P}$ is more likely than not-P, nor does the Skeptic believe that not-P is more likely than P. ${ }^{22}$ Data from the

${ }^{21}$ Data from Bourget and Chalmers.

22 This sense of 'Skepticism' is similar to Sextus Empiricus' use of the term. See Sextus Empiricus, "Outlines of Pyrrhonism." I. 4, 810. I will use the capitalized 'Skepticism' to refer to this doctrine and 'skepticism' to refer more generally to any non-Dogmatic position including both 'Skepticism' and 'Skeptical-Dogmatism' (see below). 
Bourget and Chalmers survey indicates that only a tiny fraction of philosophers hold Skeptical views. Most extant philosophical disagreement is between Dogmatists who are aware that there are competing positions held by other Dogmatists.

Obviously, the proposed understanding of 'Skepticism' is not intended as an explication of how it is used by Sextus and other Pyrrhonians. After all, it says little about many interpretative issues, e.g., the vexed question of scope: Do Pyrrhonian Skeptics suspend belief about all matters, or just some proper subset of the usual objects of belief? Our understanding of 'Skepticism' leaves open the possibility of being skeptical about some matters but not others. ${ }^{23}$

Skeptical-Dogmatism is importantly different (and, at least for some, darker and more depressing) than Skepticism: it recommends disbelieving each view, or at least believing that each view is more likely false than not. ${ }^{24}$ In other words, there are two positions that are in competition with Dogmatism about any philosophical position P: Skepticism recommends suspension of judgment about $\mathrm{P}$, and

${ }^{23}$ For some overview of these and other interpretative questions, see Diego E. Machuca, "Ancient Skepticism: Pyrrhonism," Philosophy Compass 6, no. 4 (2011): 246-58.

${ }^{24}$ The idea that the contents of beliefs can incorporate modal modifiers is important for the argument. If I know that some prize is behind one of three doors and the only options are full belief/full disbelief/suspension of belief, then the Skeptical option of suspending belief about which door the prize is behind seems appropriate. Allowing modally modified contents, however, favors believing the prize is probably not behind each door (given that the epistemic probability of the prize being behind each door is 0.33 ). I assume here (without argument) that our everyday practice of incorporating modal modifiers is appropriate, e.g." "I believe it will probably rain tomorrow". Thanks to an anonymous referee for prompting discussion of this issue. 
Skeptical-Dogmatism recommends believing that $\mathrm{P}$ is false, or probably false. ${ }^{25}$ Like the notion of 'Skepticism', the understanding of 'Skeptical-Dogmatism' is consistent with a Skeptical-Dogmatic response to some issues but not others.

\section{Multi-Proposition Disputes}

As noted above, binary disagreements are disputes where one party holds "P" and the other "not-P". Given the understanding of 'Dogmatism' and 'Skeptical-Dogmatism', we should emend this: binary disputes are disputes where one party holds that " $\mathrm{P}$, or that $\mathrm{P}$ is at least more likely true than not", and the other party holds that "not-P, or that not$\mathrm{P}$ is at least more likely true than not." We will understand 'multi-proposition disputes' to refer to disagreements about contraries, P, Q, R, etc. about some philosophical topic. Here is a partial list of multi-proposition philosophical disputes:

Distributive Justice: justice as fairness vs. libertarianism vs. socialism vs. utilitarianism

Religion: atheism vs. monotheism vs. agnosticism vs. polytheism

Ontology: materialism vs. immaterialism vs. dualism Metaphysics: compatibilism vs. hard determinism vs. libertarianism

25 The negative dogmatism discussed by Sextus is perhaps the closest historical analog of skeptical dogmatism. Often, however, 'negative dogmatism' is understood in a modally stronger way than Skeptical-Dogmatism: that it is impossible to discover philosophical truth. For the different understandings of 'negative dogmatism,' see Robert J. Hankinson, The Sceptics (Routledge, 1999).

Manuscrito - Rev. Int. Fil. Campinas, v. 45, n. 2, pp. 1-49, Apr.-Jun. 2022. 
Philosophy of Science: realism vs. empirical realism vs. constructivism

Logic: classical vs. verificationist vs. dialethic

Perceptual Experience: disjunctivism vs. qualia theory vs. representationalism vs. sense-datum theory Personal Identity: biological view vs. psychological view vs. further-fact view

Normative Ethics: virtue ethics vs. consequentialism vs. deontology

Knowledge Claims: contextualism vs. relativism vs. invariantism

Here are some (putative) examples of binary disputes:
Abortion : permissible/impermissible
Capital Punishment : permissible/impermissible
Free will: compatibilism vs. incompatibilism ${ }^{26}$

\begin{abstract}
${ }^{26}$ I refer to these as 'putative' examples of binary disputes because they are open to challenge. The permissible/impressible abortion question can be parsed further: permissible in the first trimester, second trimester, and third trimester, for example. Cases where the mother's life is at risk, the pregnancy is the result of rape, or where the fate of the universe hangs in the balance may divide proponents on both sides of the permissible/impermissible opposition. When we think of the moral status of the fetus, there are three distinct positions in the literature: the fetus has no moral status, it has full moral status, and the fetus has some (but not full) moral status. More generally, the abortion and capital punishment issues might be challenged because some might think that there is a third important category here: morally required. Thus, in the case of abortion or capital punishment, some might argue that abortion or capital punishment is morally required, not merely permissible. In the free will example, the incompatibilist camp might be further divided into hard determinism and libertarians about the will. My argument requires merely that many important philosophical disputes are best characterized as multi-proposition disputes. If it
\end{abstract}

Manuscrito - Rev. Int. Fil. Campinas, v. 45, n. 2, pp. 1-49, Apr.-Jun. 2022. 
This is not the place to try to survey the entire philosophical landscape to determine how common multiproposition disputes are, relative to binary disputes. Our cursory look suggests that multi-proposition disputes are common, and indeed, may outnumber binary disputes. Further support stems from the fact that many of the multiproposition disputes mentioned above are at a relatively high level of abstraction. Agreement about an issue at a higher level of abstraction is consistent with disagreement at lower levels of abstraction. The following example illustrates this point:

\section{Drinking by One's Lonesome}

At the Pacific APA conference, you find two philosophical colleagues who agree with you that consequentialism is the correct view in normative ethics. You have a good time shit-talking about your epistemically benighted colleagues who believe in virtue ethics or deontology. Soon, however, it turns out that your agreement about consequentialism maskes another multi-proposition dispute: you are a bedonist about the good, while one of your fellow consequentialists is a perfectionist about the good, and the third is a pluralist about the good (combining both hedonistic and perfectionist elements). Fortunately, later at the bar that evening, you discover two colleagues who are both consequentialists and hedonists about the good, so you enjoy shit-talking about the benighted consequentialists who are perfectionists and pluralists about the good. Soon, however, it turns out that your agreement about hedonism masks another multi-proposition dispute: you believe hedonic value should be analyzed in terms of attitudinal pleasure, while one ofyour fellow bedonists analyzes it in terms of sensory

can be shown that all important philosophical disputes are best characterized as multi-proposition disputes, then so much the better for my argument.

Manuscrito - Rev. Int. Fil. Campinas, v. 45, n. 2, pp. 1-49, Apr.-Jun. 2022. 
pleasure, and the third in terms of positive moods and emotions. The logical endpoint of this is where you drink vodka by your lonesome in your botel room, shit-talking to your lonesome about everyone else's epistemically benighted views.

So, agreement at the "family" level may disappear at the "genus" or "species" level. In our example, agreement about consequentialism is at the family level, while agreement about the good as either hedonistic, perfectionist, or pluralist is the genus level, and agreement about hedonism is at the species level. This is not to say that all philosophical disputes can be characterized in terms of this biological schema, nor that there is agreement about any particular hierarchy. ${ }^{27}$ Still, to the extent that such a hierarchy approximates at least some characterization of philosophical disputes, it shows that we should expect there is more agreement at the "higher levels" as compared with lower levels. ${ }^{28}$ The relevance of this to the Bourget and Chalmers survey is that many of their survey questions are about "higher level" questions like the normative ethics question. Although we do not have survey data for this, the Drinking by One's Lonesome example suggests that the $23.7 \%$ of the respondents who favored

${ }^{27}$ Indeed, this example was purposely constructed to illustrate that the strict hierarchy suggested is implausible. One might be a deontologist about right action but hold a hedonistic theory of prudential good, for example, by rejecting welfarism in normative ethics.

${ }^{28} \mathrm{I}$ am thinking here about philosophical views or theories. Normative theorists, for example, will often agree on particular prescriptive judgements about what is to be done, e.g., it is wrong to kill your neighbor simply because he started mowing his lawn at $5 \mathrm{am}$, although there may be much disagreement about why it is wrong. 
consequentialism may disagree amongst themselves about which "species" of consequentialism is correct. ${ }^{29}$

The argument requires that we have some further understanding of the sociology of philosophers' belief. In their survey, Bourget and Chalmers asked respondents about 30 philosophical disagreements. While none of the thirty questions surveyed by the authors had univocal support, several were close. The highest response for a single view was the question about the external world: non-skeptical realism came in at $81.6 \%$ (the other categories in this question include: skepticism $4.8 \%$, idealism $4.3 \%$, other $9.2 \%$ )..$^{30}$ Still, this is an impressive amount of agreement considering how often disagreement is thought to be the norm amongst philosophers.

To get some overall sense of the survey results, I suggest we classify the results into two categories: those where there is a majority endorsement of a single view, and those that do not have a majority response for a single answer. 13 of the 30 responses have a majority answer for one view. Several of these are bare majorities, e.g., the correspondence theory of truth has a $50.8 \%$ majority. If we remove the "majority" disagreements from consideration, then this still leaves 17 of the 30 .

${ }^{29}$ An anonymous reviewer writes, quite rightly in my view, "If the survey participants were to describe their own position in normative ethics instead of having to choose one out of a limited number of options, it's not clear if what they end up describing would neatly align with one of the available options." To the best of my knowledge, such an "open-ended" survey has not been conducted, so at this point it would be pure speculation whether such a survey would reveal more agreement, less agreement, or converge close to Bourget and Chalmers' survey.

${ }^{30}$ Bourget and Chalmers, "What Do Philosophers Believe?" 
In terms of philosophical adherence, the dominance of Dogmatism over its skeptical competitors is further confirmed when we appreciate that the survey permitted respondents weaker positions with respect to the likelihood of the positions under question. The survey permitted respondents to answer "Agnostic/undecided", and "Reject all". The former might be the most fitting category for Skeptics, while the latter is probably the best of the limited options for a Skeptical-Dogmatist about some dispute. ${ }^{31}$ Neither response is very popular: they were always checked off far less often than "accept" or "lean towards".

We are at last in a position to appreciate one reason why the Pyrrhonian strategy, as outlined above, has limited applicability: many disputes in philosophy are multiproposition disputes while the Pyrrhonian strategy above presupposed the binary model. We will examine below the prospects for extending the Pyrrhonian strategy to multiproposition disputes in the penultimate section.

The modest and (I hope) uncontroversial conclusion I aim to draw from this discussion is that many of our preferred philosophical views are minority positions in multi-proposition disputes. In what follows, I shall use 'multi-proposition disputes' to refer to those disputes where no single view comprises a majority.

\section{The Greater Accuracy of Skeptical-Dogmatists' Beliefs}

In this section, I hope to show that Skeptical-Dogmatism offers a higher average accuracy than Dogmatism and Skepticism in multi-proposition disputes, given the following assumptions:

31 A better option for Skeptical-Dogmatists is: "lean against all". 
I. The multi-proposition disputes comprise positions that are jointly exhaustive.

II. The multi-proposition disputes comprise positions that are mutually exclusive.

III. Egalitarianism is true.

We will examine these assumptions below. To make the case, I will work two examples. The first extends the normative ethics disputes example using data from the aforementioned survey, the second is a generic dispute with factors that favor Dogmatism.

As intimated above, our understanding of 'Dogmatism' allows us to collapse the "accept" and "lean towards" categories in Table 1. In considering the data from Bourget and Chalmers, it will help to treat the percentages in the survey data as whole numbers: this is sufficient to make the point as it preserves the relative proportion of philosopher's belief for each position. ${ }^{32}$ Since deontology is the most

32 Bourget and Chalmers, "What Do Philosophers Believe?" Here is the most comprehensive presentation of the survey data for the normative ethics question:

Normative ethics: deontology, consequentialism, or virtue ethics?

\begin{tabular}{|l|l|l|}
\hline Other & $32.3 \_1.2 \%$ & $\begin{array}{l}\text { Accept more than one (8.4\%), } \\
\text { Agnostic/undecided (5.2\%), Accept an } \\
\text { intermediate view (4.0\%), Accept another } \\
\text { alternative (3.5\%), Insufficiently familiar } \\
\text { with the issue (3.3\%), Reject all (2.7\%) }\end{array}$ \\
\hline Deontology & $25.9 \_1.1 \%$ & Lean toward (16.0\%), Accept (9.9\%) \\
\hline Consequentialism & $23.6 \_1.0 \%$ & Lean toward (14.0\%), Accept (9.7\%) \\
\hline Virtue ethics & $18.2 \_0.9 \%$ & Lean toward (12.6\%), Accept (5.6\%) \\
\hline
\end{tabular}

Manuscrito - Rev. Int. Fil. Campinas, v. 45, n. 2, pp. 1-49, Apr.-Jun. 2022. 
common Dogmatic position in the dispute about normative ethics, I will assume that this position is correct. This is dialectically advantageous to Dogmatists. Looking at the deontologist row in Table 2, we see that deontologists are right about deontology being the correct position, and they are correct in disbelieving consequentialism and virtue theory. Looking at the next two rows, we can see that consequentialists are correct to disbelieve virtue theory, and virtue theorists are correct to disbelieve consequentialism. However, consequentialists are wrong to believe in consequentialism and wrong to disbelieve deontology. Similarly, virtue theorists are wrong to believe virtue theory and wrong to disbelieve deontology.

Table 2: Dogmatists' Net Accuracy in Normative Ethics Dispute

\begin{tabular}{|c|c|c|c|c|c|c|}
\hline Number & View & $\begin{array}{c}\text { Deontology } \\
\text { [True] }\end{array}$ & $\begin{array}{c}\text { Consequentialism } \\
\text { [False] }\end{array}$ & $\begin{array}{c}\text { Virtue Ethics } \\
\text { [False] }\end{array}$ & Total R & Total -W \\
\hline 26 & Deontologists & [believe] = R $(26)$ & [disbelieve] = R (26) & {$[$ disbelieve] = R (26 } & 78 & 0 \\
\hline 24 & Consequentialists & [disbelieve] $=-\mathrm{W}(-24)$ & [believe] $=-\mathrm{W}(-24)$ & [disbelieve] = R (24 & 24 & -48 \\
\hline 18 & Virtue Ethicists & [disbelieve] $=-W(-18)$ & [disbelieve] = R (18) & {$[$ believe] $=-W(-18)$} & 18 & -36 \\
\hline 68 & Total & & & & 120 & -84 \\
\hline
\end{tabular}

In some ways this is good news for Dogmatists, since Table 2 shows that the Dogmatists have more true beliefs than false beliefs. ${ }^{33}$ The net accuracy of Dogmatists is 36, while their average accuracy is 0.53 .

Suppose the 68 undergo a doxastic conversion (perhaps as a result of the use of the Cruel God's app) and become

33 The reliability of philosophers' beliefs has been questioned by some. See for example Sanford C. Goldberg, "Reliabilism in Philosophy," Philosophical Studies 142, no. 1 (2009): 105-17. The "good news" here is that on average, philosophers are more reliable than a coin flip for determining whether to believe or disbelieve each of these views. 
Skeptical-Dogmatists. Table 3 shows that their net accuracy is now 68 , and their average accuracy rises to 1.0.

Table 3: Skeptical-Dogmatists' Net Accuracy in Normative Ethics Dispute

\begin{tabular}{|c|c|c|c|c|c|c|}
\hline Number & Position & $\begin{array}{c}\text { Deontology } \\
\text { [True] }\end{array}$ & $\begin{array}{c}\text { Consequentialism } \\
\text { [False] }\end{array}$ & $\begin{array}{c}\text { Virtue Ethics } \\
\text { [False] }\end{array}$ & Total R & Total -W \\
\hline 68 & $\begin{array}{l}\text { Skeptical- } \\
\text { Dogmatism }\end{array}$ & [disbelieve] $=-\mathrm{W}(-68)$ & [disbelieve] = R (68) & [disbelieve] = R (68) & 136 & -68 \\
\hline
\end{tabular}

So, Skeptical-Dogmatism outperforms Dogmatism in terms of accuracy. Skeptical-Dogmatism also outperforms Skepticism. Imagine the 68 had become Pyrrhonians rather than Skeptical-Dogmatists as a result of the doxastic app. In this case, their net accuracy is 0 . So, both Dogmatism and Skeptical-Dogmatism outperform Skepticism (given the assumptions of the case).

We can also show that Skeptical-Dogmatists will always have greater accuracy for any multi-proposition dispute as defined above, that is, where there are three or more contrary positions in which no one position has a majority of adherents. To illustrate, we will assume that there are three generic philosophical positions in a multi-proposition dispute. To make this as dialectically advantageous for Dogmatists as possible, we will again assume the most popular of the three is the correct view.

Table 4: Dogmatists' Net Accuracy in A Generic MultiProposition Dispute

\begin{tabular}{|c|c|c|c|c|c|c|}
\hline Number & View & $\begin{array}{c}\text { Generic } 1 \\
\text { [True] }\end{array}$ & $\begin{array}{c}\text { Generic } 2 \\
\text { [False] }\end{array}$ & $\begin{array}{c}\text { Generic } 2 \\
\text { [False] }\end{array}$ & Total R & Total -W \\
\hline 49 & Pro Generic 1 & [believe] = R (49) & [disbelieve] = R (49) & [disbelieve] = R (49) & 147 & 0 \\
\hline 25 & Pro Generic 2 & [disbelieve] $=-W(-25)$ & [believe] $=-\mathrm{W}(-25)$ & [disbelieve] = R (25) & 25 & -50 \\
\hline 25 & Pro Generic 3 & [disbelieve] $=-W(-25)$ & [disbelieve] = R (25) & [believe] $=-\mathrm{W}(-25)$ & 25 & -50 \\
\hline 99 & Total & & & & 197 & -100 \\
\hline
\end{tabular}

Manuscrito - Rev. Int. Fil. Campinas, v. 45, n. 2, pp. 1-49, Apr.-Jun. 2022. 
Table 5: Skeptical-Dogmatists' Net Accuracy in Generic Multi-Proposition Dispute

\begin{tabular}{|c|c|c|c|c|c|c|}
\hline Number & Position & $\begin{array}{c}\text { Generic 1 } \\
{[\text { True] }}\end{array}$ & $\begin{array}{c}\text { Generic 2 } \\
\text { [False] }\end{array}$ & $\begin{array}{c}\text { Virtue Ethics } \\
{[\text { False] }}\end{array}$ & Total R & Total -W \\
\hline 99 & $\begin{array}{c}\text { Skeptical- } \\
\text { Dogmatism }\end{array}$ & $\begin{array}{c}\text { [disbelieve] = -W (-99) } \\
{[\text { [disbelieve] = R (99) }}\end{array}$ & [disbelieve] =R (99) & 198 & -99 \\
\hline \multicolumn{7}{|c|}{ Net Accuracy: 99 } \\
\hline
\end{tabular}

So, even assuming every advantage for Dogmatism, as Table 4 indicates, Dogmatists have a net accuracy of 97 , and an average accuracy of 0.98 , while Table 5 indicates that Skeptical-Dogmatists have a net accuracy of 99, and an average of 1.0 .

As noted above, the survey data shows that many extant philosophical disagreements are such that there is no majority view. Under the specified assumptions, SkepticalDogmatists are assured to have a higher average accuracy than Dogmatists.

In the next three sections we will examine assumptions IIII above.

\section{Jointly Exhaustive}

The assumption that the extant list of views in multiproposition disputes is jointly exhaustive is almost certainly false. After all, it seems to preclude any development of novel theoretical approaches to philosophical questions: as if the task of all future philosophy is to paint "grey on grey". ${ }^{34}$ However, as we shall see, rejecting this assumption favors the Skeptical-Dogmatist, not the Dogmatist.

To see why, suppose a competitor theory to the big three in normative theory is proposed by a brilliant philosopher in

${ }^{34}$ Georg Wilhelm Fredrich Hegel, Hegel: Elements of the Philosophy of Right (Cambridge University Press, 1991).

Manuscrito - Rev. Int. Fil. Campinas, v. 45, n. 2, pp. 1-49, Apr.-Jun. 2022. 
the twenty-second century. We will refer to this theory as ' $\mathrm{X}$ '. There are two cases to consider: (i) $\mathrm{X}$ is false and one of the original big three is true, or (ii) $\mathrm{X}$ is true and all the big three are false.

If the former, then, there are again two cases: Dogmatists and Skeptical-Dogmatists do not have beliefs about X, or they have beliefs about X. If we assume that Dogmatists and Skeptical-Dogmatists do not have beliefs about X since they have not thought about $\mathrm{X}$, then their accuracy with respect to $\mathrm{X}$ is the same as suspended judgement, that is, 0 . So, their accuracy remains unaffected. If we assume that Dogmatists and Skeptical-Dogmatists have beliefs about X, then both Dogmatists and Skeptical-Dogmatists will hold that $\mathrm{X}$ is false, or at least probably false. (Dogmatists may reason that any view that is incompatible with their preferred view is wrong, or probably wrong.) So, the existence of a false $\mathrm{X}$ does not reverse the fortunes of Dogmatism.

If $\mathrm{X}$ is true, then it follows that the big three are all false. Interestingly, the accuracy of Dogmatists increases when the big three are all false, as shown in Table 6.

Table 6: Dogmatists' Net Accuracy in Normative Ethics Dispute Given that $\mathrm{X}$ is True

\begin{tabular}{|c|c|c|c|c|c|c|}
\hline Number & View & $\begin{array}{c}\text { Deontology } \\
\text { [False] }\end{array}$ & $\begin{array}{l}\text { Consequentialism } \\
\text { [False] }\end{array}$ & $\begin{array}{l}\text { Virtue Ethics } \\
\text { [False] }\end{array}$ & Total R & Total $-\mathrm{W}$ \\
\hline 26 & Deontologists & [believe] $=-\mathrm{W}(-26)$ & [disbelieve] = R (26) & [disbelieve] = R (26) & 52 & -26 \\
\hline 24 & Consequentialists & [disbelieve] $=R(24)$ & [believe] $=-\mathrm{W}(-24)$ & [disbelieve] = R (24 & 48 & -24 \\
\hline 18 & Virtue Ethicists & {$[$ disbelieve] $=R(18)$} & [disbelieve] = R (18) & [believe] $=-W(-18)$ & 36 & -18 \\
\hline 68 & Total & & & & 136 & -68 \\
\hline
\end{tabular}

The average accuracy of Skeptical-Dogmatists also goes up on the assumption that $\mathrm{X}$ is true, as shown in Table 7. 
Table 7: Skeptical-Dogmatists' Net Accuracy in Normative Ethics Dispute Given That X Is True

\begin{tabular}{|l|l|c|c|c|l|l|}
\hline Number & Position & $\begin{array}{c}\text { Deontology } \\
\text { [False] }\end{array}$ & $\begin{array}{c}\text { Consequentialism } \\
\text { [False] }\end{array}$ & $\begin{array}{c}\text { Virtue Ethics } \\
\text { [False] }\end{array}$ & Total R & Total -W \\
\hline 68 & $\begin{array}{l}\text { Skeptical- } \\
\text { Dogmatism }\end{array}$ & [disbelieve] = R (68) & [disbelieve] = R (68) & [disbelieve] =R (68) & 204 & 0 \\
\hline \multicolumn{7}{|c|}{ Net Accuracy: 204 } \\
\hline
\end{tabular}

So, if the assumption that the set of views is jointly exhaustive is false, then either Skeptical-Dogmatism maintains its accuracy lead over Dogmatism (if the true view is amongst those presently held), or Skeptical-Dogmatism increases its accuracy advantage over Dogmatism (average 3 versus average 1) if the true view is amongst those not presently held.

\section{Mutually Exclusive}

There are various ways to challenge the assumption that multi-proposition disputes are mutually exclusive, e.g., one theory might entail another, or two theories might be mutually entailing. For the sake of economy of exposition, I will concentrate on perhaps the worst possibility for the argument here, namely, that there are no multi-proposition disputes: there are only apparent multi-proposition disputes - they are at their core identical.

To work again the normative ethics example, let us suppose that deontology, consequentialism, and virtue ethics are identical. To keep the exposition manageable, let us assume the three theories are the only normative theories philosophers have beliefs about. Suppose one of the theories is false, in which case, all three theories are false. This will yield the same accuracy as described in Tables 6 and 7: the average accuracy of Dogmatists is 1 , whereas the average accuracy of Skeptical-Dogmatists is 3. 
Suppose one of the theories is true, in which case all three are true. Tables 8 and 9 describe the resulting levels of accuracy:

Table 8: Dogmatists' Net Accuracy Calculated Using Egalitarianism on The Assumption That the Big Three Are Identical and True

\begin{tabular}{|c|c|c|c|c|c|c|}
\hline Number & Position & $\begin{array}{l}\text { Deontology } \\
\text { [True] }\end{array}$ & $\begin{array}{c}\text { Consequentialism } \\
\text { [True] }\end{array}$ & $\begin{array}{c}\text { Virtue Ethics } \\
\text { [True] }\end{array}$ & Total R & Total -W \\
\hline 26 & Deontologist & [believe], R (26) & [disbelieve], -W (-26) & [disbelieve], -W (-26) & 26 & -52 \\
\hline 24 & Consequentialist & [disbelieve], $-\mathrm{W}(-24)$ & [believe], R (24) & [disbelieve], -W (-24) & 24 & -48 \\
\hline 18 & Virtue Ethics & [disbelieve], -W (18) & [disbelieve], -W (-18) & [believe], R (18) & 18 & -36 \\
\hline 68 & Total & & & & 68 & -136 \\
\hline \multicolumn{7}{|c|}{ Net Accuracy: -68} \\
\hline
\end{tabular}

Since Skeptical-Dogmatists disbelieve each of the views, and all three are true, it follows that Skeptical-Dogmatists have all false beliefs, that is, an average accuracy of -3.0.

Table 9: Skeptical-Dogmatists' Net Accuracy in Normative Ethics Dispute Using Egalitarianism on the Assumption that the Big Three Are Identical and True

\begin{tabular}{|l|l|c|c|c|c|c|}
\hline Number & Position & $\begin{array}{c}\text { Deontology } \\
{[\text { True] }}\end{array}$ & $\begin{array}{c}\text { Consequentialism } \\
{[\text { True] }}\end{array}$ & $\begin{array}{c}\text { Virtue Ethics } \\
{[\text { True] }}\end{array}$ & Total R & Total -W \\
\hline 68 & $\begin{array}{l}\text { Skeptical- } \\
\text { Dogmatism }\end{array}$ & {$[$ disbelieve] = -W (-68) } & [disbelieve] = -W (-68) & [disbelieve] = -W (-68) & 0 & -204 \\
\hline \multicolumn{5}{|c|}{ Net Accuracy: -204 } \\
\hline
\end{tabular}

So, we have found a possibility where Dogmatism does better than Skeptical-Dogmatism in terms of accuracy. How much solace should Dogmatists find in this? I hope to show that the answer is "not much".

Think of 'convergence' as instances where apparent multi-proposition views are in fact not contraries, but refer 
to one and the same theory. ${ }^{35}$ A single instance of convergence, for example, may favor the Dogmatist, but there are many (at least apparent) multi-proposition disputes. So, if convergence is to help Dogmatists, then convergence must be a widespread phenomenon.

To assess the plausibility of widespread convergence, it will help to lay out a competitor view, which I shall refer to as "speciation". By this, I mean the idea that theoretical views tend to branch to form an ever-increasing diversity of views. This was intimated in the Drinking by One's Lonesome example. Consider this familiar view of the history of utilitarianism: Jeremy Bentham was the first to fully formulate utilitarianism (although earlier thinkers held similar views in the history of philosophy). Since Bentham's original formulation, utilitarianism has divided into a dizzying array of theories, including disputes over the nature of the good (e.g., pleasure, happiness, preferences, motivations, pain reduction), the objects of evaluation (e.g., acts, rules, motivations, or institutions), and threshold (e.g., maximizing, satisficing, or average utility). This is just some

35 The closest recent example of convergence I can think of is Derek Parfit's D. Parfit, Reasons and Persons (Oxford: Oxford University Press, 1987). For some indication of the extent to which, even granting his main claims, Parfit's work falls very far short of convergence, as understood here, see Marius Baumann, "Parfit, Convergence, and Underdetermination," J. Ethics \& Soc. Pbil. 13 (2018): 191. More generally, the argument here is consistent with the idea that there may be significant overlap between competitor views. As an anonymous reviewer writes, "While it'd be a stretch to maintain that deontology, utilitarianism and virtue ethics are essentially identical, it's possible that certain tenets of one theory are compatible with-if not similar to-key tenets of the other." The reviewer's point seems undeniable: If widespread agreement about such tenets can be identified, the accuracy argument would not apply to these. 
of the possible variants that utilitarianism has developed into. ${ }^{36}$ One may disagree over the details, whether, for example, Bentham really deserves the crown as the first utilitarian, and still agree with the speciation view.

If the speciation view is correct, then it seems we should expect, other things being equal, more disagreement over time, since there are more articulated positions from philosophers to choose from, and most of these appear to have champions. Of course, if the widespread convergence view is correct, then this apparent history must be seriously misleading. What might account for this appearance? Ernest Sosa has (famously) claimed he is "convinced that much disagreement on controversial issues, especially in philosophy, has that deeply verbal nature." 37 If we think of this as the "verbal slippage" explanation, then philosophical disagreements are often not genuine multi-proposition disagreements in the sense defined, since often there is no dispute about contrary positions.

There seems little reason to suppose that the idea of mere verbal disputes will offer much support for the widespread convergence thesis. First, Sosa acknowledges that he offers little evidence for his claim; rather, he punts, suggesting that "...case studies, such as that of the disagreement among epistemologists on issues concerning epistemic "justification"' 38 might be used to establish his thesis. The idea appears to be to use something like an inductive strategy: a series of such case studies might be used to establish the more general claim that mere verbal slippage

${ }^{36}$ Julia Driver, "The History of Utilitarianism," 2014.

${ }^{37}$ Ernest Sosa, "The Epistemology of Disagreement," in Social Epistemology (New York: Oxford University Press, 2010), 278-97. At 281 .

${ }^{38}$ Sosa. At 281. 
might explain much philosophical disagreement. As Sosa no doubt would agree, the promise of an argument hardly carries the same evidential weight as the argument itself. Note too that it would not be sufficient support for the widespread convergence thesis to say that some (putative) philosophical disagreements are the result of verbal slippage. It requires the more ambitious thesis, that many or most disagreements are the result of verbal slippage. ${ }^{39}$

Second, it should be noted that even granting that there is widespread slippage is not sufficient to establish the "mere verbal" disputes hypothesis. Consider that once a verbal slippage is identified, there are three possible outcomes. First, as Sosa mentions, revelation of the verbal slippage may resolve the apparent dispute. Second, revelation of the verbal slippage may do nothing to resolve the dispute. Finally, a dispute might intensify after revelation of verbal slippage. Imagine a libertarian and a socialist agree about the importance of the political value of freedom, but disagree about the importance of equality. When it is discovered that there is verbal slippage in how the two understand 'freedom', the initial agreement about the importance of freedom may dissipate. For example, the libertarian may disagree that freedom is important when understood by the socialist as 'the ability to make authentic choices and act upon them', and the socialist might disagree with the libertarian's notion of freedom as 'absence of governmental restraints, except in preservation of natural rights'. If Sosa is right, most verbal slippages would have to fall into the first category. However, there is no reason, at least at present, to think this is the case.

The prospects for widespread convergence do not look good. And in terms of Dogmatists avoiding some form of

39 For more on the prospects for this line of argument, see Nathan Ballantyne, "Verbal Disagreements and Philosophical Scepticism," Australasian Journal of Philosophy 94, no. 4 (2016): 752-65.

Manuscrito - Rev. Int. Fil. Campinas, v. 45, n. 2, pp. 1-49, Apr.-Jun. 2022. 
skepticism, the prospect of widespread convergence simply trades one form of skepticism (Skeptical-Dogmatism) for another: skepticism about our ability to distinguish philosophical views. Indeed, there is the worry that if convergence were widespread, it may cast into doubt the distinction between Dogmatism, Skepticism, and SkepticalDogmatism itself.

\section{Cautiousness, Skeptical-Dogmatism, and Skepticism}

I suggested above that the assumption of Egalitarianism favors Dogmatists. In this section, I hope to support this claim by looking at three versions of Cautiousness: Moderate, Extreme, and Super Extreme.

For Moderate Cautiousness we will use the same values employed above, namely, $\mathrm{R}=1$ and $-\mathrm{W}=-1.1$. Table 10 shows that the accuracy of Dogmatists declines when applying Moderate Cautiousness to our generic multiproposition dispute:

Table 10: Dogmatists' Net Accuracy in a Generic MultiProposition Dispute Calculated Using Moderate Cautiousness

\begin{tabular}{|c|c|c|c|c|c|c|}
\hline Number & Position & $\begin{array}{c}\text { Generic } 1 \\
\text { [True] }\end{array}$ & $\begin{array}{c}\text { Generic } 2 \\
\text { [False] }\end{array}$ & $\begin{array}{c}\text { Generic } 3 \\
\text { [False] }\end{array}$ & Total R & Total W \\
\hline 49 & Pro Generic 1 & [Believe] = R (49) & [Disbelieve] = R (49) & [Disbelieve] = R (49) & 147 & 0 \\
\hline 25 & Pro Generic 2 & [Disbelieve] $=-\mathrm{W}(-27.5)$ & [Believe] $=-\mathrm{W}(-27.5)$ & [Disbelieve] = R (25) & 25 & -55 \\
\hline 25 & Pro Generic 3 & {$[$ Disbelieve] $=\mathrm{W}(-27.5)$} & [Disbelieve] = R (25) & {$[$ Believe] $=-W(-27.5)$} & 25 & -55 \\
\hline 99 & Total & & & & 197 & -110 \\
\hline \multicolumn{7}{|c|}{ Net Accuracy 87} \\
\hline
\end{tabular}

Table 11 shows that the accuracy of Skeptical-Dogmatists declines when applying Moderate Cautiousness to our generic multi-proposition dispute: 
Table 11: Skeptical-Dogmatists' Net Accuracy in Generic Multi-Proposition Dispute Calculated Using Moderate Cautiousness

\begin{tabular}{|c|c|c|c|c|c|c|}
\hline Number & Position & $\begin{array}{c}\text { Generic 1 } \\
{[\text { True] }}\end{array}$ & $\begin{array}{c}\text { Generic 2 } \\
{[\text { False] }}\end{array}$ & $\begin{array}{c}\text { Virtue Ethics } \\
{[\text { False] }}\end{array}$ & Total R & Total -W \\
\hline 99 & $\begin{array}{c}\text { Skeptical- } \\
\text { Dogmatism }\end{array}$ & [disbelieve] = -W (-108.9) & {$[$ disbelieve] = R (99) } & [disbelieve] =R (99) & 198 & -108.9 \\
\hline \multicolumn{7}{|c|}{ Net Accuracy: 89.1} \\
\hline
\end{tabular}

So, while the accuracy for both declines, SkepticalDogmatism slightly increases its advantage over Dogmatism. And both the Dogmatist and the Skeptical-Dogmatist have a greater average accuracy than the Skeptic, whose accuracy of course remains at 0.0 .

Extreme Cautiousness we will define as follows: $\mathrm{R}=1$ and $-\mathrm{W}=-2$. As Tables 12 and 13 show, the accuracy of both Dogmatism and Skeptical-Dogmatism declines with Extreme Cautiousness, with Skeptical-Dogmatism again increasing its advantage over Dogmatism.

Table 12: Dogmatists' Net Accuracy in a Generic MultiProposition Dispute Calculated Using Extreme Cautiousness

\begin{tabular}{|c|c|c|c|c|c|c|}
\hline Number & Position & $\begin{array}{c}\text { Generic } 1 \\
\text { [True] }\end{array}$ & $\begin{array}{c}\text { Generic } 2 \\
\text { [False] }\end{array}$ & $\begin{array}{c}\text { Generic } 3 \\
\text { [False] }\end{array}$ & Total R & Total W \\
\hline 49 & Pro Generic 1 & [Believe] = R (49) & [Disbelieve] = R (49) & [Disbelieve] = R (49) & 147 & 0 \\
\hline 25 & Pro Generic 2 & [Disbelieve] $=-\mathrm{W}(-50)$ & {$[$ Believe] $=-W(-50)$} & [Disbelieve] = R (25) & 25 & -100 \\
\hline 25 & Pro Generic 3 & [Disbelieve] = W $(-50)$ & [Disbelieve] = R (25) & {$[$ Believe] $=-W(-50)$} & 25 & -100 \\
\hline 99 & Total & & & & 197 & -200 \\
\hline \multicolumn{7}{|c|}{ Net Accuracy -3 } \\
\hline
\end{tabular}

Table 13: Skeptical-Dogmatists' Net Accuracy in a Generic Multi-Proposition Dispute Calculated Using Extreme Cautiousness

\begin{tabular}{|l|l|l|l|l|l|l|}
\hline Number & Position & Generic 1 & Generic 2 & Generic 3 & Total R & $\begin{array}{l}\text { Total } \\
\text { W }\end{array}$ \\
\hline 99 & $\begin{array}{l}\text { Skeptical- } \\
\text { Dogmatism }\end{array}$ & [Disbelieve] = W (-198) & [Disbelieve] = R (99) & [Disbelieve] = R (99) & 198 & -198 \\
\hline \multicolumn{5}{|c|}{ Net Accuracy 0.0 } \\
\hline
\end{tabular}


Under these assumptions, the accuracy of the SkepticalDogmatists is the same as that of Skeptics, with both beating out Dogmatism. Any penalty greater than -2 for $-\mathrm{W}$ - call any of these views 'Super Extreme Cautiousness'-will tip accuracy considerations in favor of Skepticism, as the Skeptical-Dogmatist's accuracy will go negative at this point.

This is not the place to consider in detail the prospects for Skepticism using Super Extreme Cautiousness. Briefly, however, this much seems apparent: much depends on whether one accepts the normative or psychological understanding of Skepticism. ${ }^{40}$ If one accepts a normative conception of Skepticism-something along the lines that one ought to suspend judgement-then the burden for Skepticism using this line of argument will be to show that we should adopt some form of Super Extreme Cautiousness. If the psychological understanding of Skepticism is correct-something along the line that the Skeptic finds herself suspending judgment-then one possibility of explaining why one finds oneself suspending judgement is that one finds oneself in conformity with Super Extreme Cautiousness.

40 This distinction is common in the literature. For representative examples see: Machuca, "Ancient Skepticism." Harald Thorsrud, Ancient Scepticism (University of California Press, 2009). My impression is that the psychological understanding is the most common interpretation of Sextus Empiricus' brand of Skepticism. 


\section{The Ethics of Philosophers' Belief}

The Cruel God's directions to you were to use Egalitarianism to calculate accuracy. ${ }^{41}$ So, the answer to the challenge is to set the app so that all philosophers are Skeptical-Dogmatists, that is, set the app to "disbelieve P, or at least believe P is more likely false than not", where P stands for each position in a multi-proposition dispute. As indicated, this would guarantee an increase in the number of true beliefs and reduce the number of false beliefs, both in aggregate and on average. Let us refer to this as the 'accuracy argument'.

The accuracy argument appears to have direct implications for the Socratic conception of philosophy noted in the epigraph: "living according to reason, conceived as a capacity for argument and analysis in pursuit of the truth." Consider that if the accuracy argument is correct, then the Cruel God is right that a competent undergraduate can easily reason her way to having more true philosophical beliefs and fewer false philosophical beliefs than the average philosopher. Ulyssa, let us imagine, caught the philosophy bug during her first and only philosophy course. Inspired by reading Plato's portrayal of Socrates, she fervently seeks to have true philosophical beliefs and avoid false philosophical beliefs. Ulyssa does not want to be like one of the hubristic interlocutors Socrates often encounters, Ion or Euthyphro, for example, who seem overly optimistic about their abilities to ascertain the truth about philosophical matters. She realizes that, after applying a bit of elementary probabilistic reasoning to data about the sociology of philosophical belief, by disbelieving each position in multi-proposition disputes

41 As intimated in the previous section, the Cruel God could have stipulated to use moderate Cautiousness and the same point in this paragraph would follow.

Manuscrito - Rev. Int. Fil. Campinas, v. 45, n. 2, pp. 1-49, Apr.-Jun. 2022. 
she has more true beliefs and fewer false beliefs than the average philosopher. ${ }^{42}$

Let us imagine that Ulyssa points her fingers at philosophers collectively and taunts, "Na-na, na-na, booboo, the accuracy of your philosophical beliefs is doo-doo." Given that the accuracy argument is sound, what significance does Ulyssa's taunt have for the question of whether philosophers should revise their doxastic attitudes? This question, which I shall refer to as the "revision" question, involves complex issues regarding the ethics of philosophical belief. In the space that remains, I shall try to sketch answers by evidentialists and non-evidentialists - the two main views in this dispute-leaving for another occasion the question of which of these is the most plausible. ${ }^{43}$

For present purposes, we need only a very rough characterization of 'evidentialism' and 'non-evidentialism'. We will understand evidentialism as the view that a person

${ }^{42}$ Just to be clear: the fact that Ulyssa has an accuracy advantage over the average philosopher is not to claim any other epistemic advantage for her, e.g., it is plausible to suppose that her understanding of the disputes is far below that of the average philosopher.

${ }^{43}$ I follow suit here dividing the ethics of belief question in terms of evidentialist versus non-evidentialism. A number of recent publications on the ethics of belief parse the issues this way. See Andrew Chignell, "The Ethics of Belief," in Stanford Encyclopedia of Philosophy, 2018, https://plato.stanford.edu/entries/ethics-belief/. D. M. Mittag, Evidentialism. Internet Encyclopedia of Philosophy, 2015. Miriam Schleifer McCormick, Believing against the Evidence: Agency and the Ethics of Belief (Routledge, 2014). Scott Aikin, Evidentialism and the Will to Believe (New York: Bloomsbury USA, 2014). (In fact, I'm not aware of any discussions that do not parse the dispute in this way.) However, I suspect that the dispute might be better parsed in terms of accuracy vs non-accuracy norms for belief. See footnote 48 for some support for this slightly heretical view.

Manuscrito - Rev. Int. Fil. Campinas, v. 45, n. 2, pp. 1-49, Apr.-Jun. 2022. 
in justified in believing $\mathrm{P}$ is true (at some particular time) if and only if one's evidence for $\mathrm{P}$ supports believing that $\mathrm{P}$ is true. ${ }^{44}$ William Clifford is often cited as paradigm example of a very robust form of evidentialism: famously he claims that "it is wrong always, everywhere, and for anyone, to believe anything upon insufficient evidence." 45 Much of the argument for his thesis involves the pernicious consequences of false beliefs, both direct harms and testimonial harms. ${ }^{46}$ Non-evidentialism is the view that there are non-evidential justifying reasons for belief. William James' essay, “The Will to Believe", is often paired with Clifford's piece as the locus classicus for the non-evidentialist position. James writes, "Our passional nature not only lawfully may, but must, decide an option between propositions, whenever it is a genuine option that cannot by its nature be decided on intellectual grounds...." 47 James used the locution, "decided on intellectual grounds", to refer to something like Sextus' equipollence: situations where we lack evidence that favors $\mathrm{P}$ over not-P, and vice versa. James claims that in some cases of intellectual equipollence, we are permitted or obliged to believe either P or not-P on "passional grounds". James suggests prudential, moral, or non-evidential epistemic reasons may be sufficient to justify belief. James mainly

${ }^{44}$ This is a fairly standard "broad strokes" understanding of 'evidentialism'. For similar presentations and some of the more common refinements see for example, Mittag, Evidentialism. Internet Encyclopedia of Philosophy. Chignell, "The Ethics of Belief."

45 William Kingdon Clifford, The Ethics of Belief and Other Essays (Prometheus Books, 2010).

${ }^{46}$ For some discussion of Clifford's thesis about the social value of true belief see Allan Hazlett, $A$ Luxury of the Understanding: On the Value of True Belief (OUP Oxford, 2013). Pp. 121-124.

47 William James, The Will to Believe (Routledge, 2014). 
focused on the case of religious belief, but there are plenty of "everyday" examples to support the idea that it is permissible to hold beliefs that are impermissible when judged solely by evidentialist strictures, including the optimistic batter's belief that he will get a hit each time at bat. Judged by evidentialist standards, the belief is impermissible, since the optimistic batter is aware that his lifetime batting average is 0.333 . Judged by non-evidentialist standards, the batter's belief may be judged as permissible: his optimistic belief increases his batting performance. We might imagine, for example, that if he believed he was not likely to get a hit, this would lead to a lower batting average and unemployment. ${ }^{48}$ The idea then is that the prudential benefit the optimistic batter receives from this belief justifies the belief. ${ }^{49}$ As for moral reasons, it may be thought that loyalty

${ }^{48}$ It seems that the optimistic batter's belief is also not justified according to some forms of externalism, e.g., Goldman's reliabilism. The optimistic batter's belief is a result of wishful thinking. Since wishful thinking is not generally a reliable or truth conducive process, the reliabilist thus has reason to reject the idea that the optimistic batter's belief is justified. Furthermore, the same sort of move that some evidentialists use to get around these sorts of purported counterexamples might also work for reliabilists, e.g., evidentialism and reliabilism offer a theory of epistemic justification, while those who claim the optimistic batter's belief is justified have something like prudential justification in mind. What seems to unite the evidentialist and the reliabilist is the idea that epistemic justification is concerned with some sort of accuracy or truth connection. It will take us too far afield to discuss these issues; hence, as noted above, I follow suit in parsing the ethics of belief question in terms of evidentialism versus non-evidentialism.

49 Often non-evidentialists suggest that prudentially beneficial beliefs that are not supported by the evidence must also not be morally pernicious. For some discussion of this stipulation, see McCormick, Believing against the Evidence. Chapter 3. 
to a friend justifies believing she is innocent despite a mountain of evidence that indicates otherwise. ${ }^{50}$

Let us look at non-evidentialist justification of philosophical belief before turning to the evidentialist response. Suppose that Dogmatic philosophical beliefs, at least on some occasions, provide greater prudential benefits than those of a Skeptical-Dogmatist, e.g., imagine one is more likely to get a paper published (ahem), secure a job, etc., when holding Dogmatic rather than Skeptical-Dogmatic beliefs. ${ }^{51}$ Similarly we may suppose that at least some Dogmatic philosophical beliefs have better moral outcomes, e.g., suppose remaining Dogmatic about some position manifests loyalty to one's mentor or philosophical faction in a way that being a Skeptical-Dogmatist does not. Finally, let us grant that there are epistemic norms other than accuracy for permissible belief. Suppose that Dogmatic philosophical beliefs work better than Skeptical-Dogmatic beliefs with non-accuracy epistemic norms for philosophical belief, e.g., "reflective equilibrium", systemizing our "opinions", or "breaking the crust of convention". ${ }^{2}$

50 The optimistic batter and loyal friend examples are drawn from Richard Feldman, Epistemology (Pearson College Division, 2003). Feldman's response to these examples is to suggest that evidentialism should be understood as a theory of epistemic justification. The fact that the optimistic batter and the loyal friend's belief are not epistemically justified is consistent with them being justified in terms of prudential benefit or for moral reasons.

${ }^{51}$ To make the example work, suppose that holding the relevant beliefs when writing an article, giving a presentation, etc., are causally productive in the way that the optimistic batter's optimistic belief helps him improve his batting average. That is, it would not be enough to simply fake having the relevant beliefs.

52 Respectively: J. Rawls, A Theory of Justice (Harvard University Press, 1971). David Kellogg Lewis, Pbilosophical Papers: Volume I (Oxford university press, 1983). Dewey John, "Art as Experience," 
Assuming that there are non-evidential reasons for belief, the non-evidentialist has a compelling answer to Ulyssa's taunt, namely:

You are correct that there is good evidence that the beliefs of a Skeptical-Dogmatist (and so your beliefs) are more accurate than ours. Nevertheless, our Dogmatic philosophical beliefs are justified because there are compelling non-evidential reasons for our belief. Hence, the accuracy argument does not offer compelling reasons for doxastic revision, that is, to become SkepticalDogmatists.

Of course, this response assumes the truth of nonevidentialism, and this is obviously not the place to decide the evidentialism vs non-evidentialism issue. Let me mention a few obstacles for this non-evidentialist defense of philosophers' beliefs

First, note that the form of non-evidentialism presupposed in this response is more robust than that promoted by James. Recall that James's position says that our passional natures may decide an issue when the intellect can't decide, that is, where the evidence neither favors P nor notP. If the accuracy argument is sound, then there is evidence that favors Skeptical-Dogmatic doxastic attitudes over Dogmatism. So, invoking the non-evidentialist response to

New York: Minton, Balch, and Company, 1934. It may be that these are endorsed by their authors as only proximate goals, e.g., reflective equilibrium is a way station on the way to truth. Still, at least some of their followers seem to endorse these not as proximate goals, but as reasonable aims for philosophy. Another possibility might to be plump for long-term accuracy: our disagreements today (involving many false beliefs) may yield the future benefit of more accurate beliefs in the long-term.

Manuscrito - Rev. Int. Fil. Campinas, v. 45, n. 2, pp. 1-49, Apr.-Jun. 2022. 
the revision question requires a version where non-evidential reasons may give us permission to believe $\mathrm{P}$, even when there is evidence favoring not-P. .53

Second, a non-evidentialist defense of philosophical belief seems to require weighing in on the question of criteria for when beliefs may be held in absence (or against) one's evidence. James famously outlined several conditions, including the idea that the hypothesis believed must be "live", "forced", and "momentous". While it will take us too far afield to examine James' strictures for non-evidentially justified belief, ${ }^{54}$ we can still appreciate the important point that non-evidentialists do not intend to countenance any manner of wishful thinking, conspiracy beliefs, etc., as doxastically justified. Thus, it seems a complete defense of non-evidentialism requires some account of how to draw the line between those beliefs that are justified non-evidentially, and those that are not. ${ }^{55}$

A third obstacle for the non-evidentialist is to provide some account of philosophical disagreement. If you hold your philosophical position P for non-evidentialist reasons, and two others hold their contrary philosophical positions $\mathrm{Q}$, and $\mathrm{R}$, for non-evidential reasons, then it is not clear how to explain the disagreement, or whether there even is a disagreement. Your peers may acknowledge that you have good non-evidential reasons for believing $\mathrm{P}$, and you may

${ }^{53}$ McCormick allows, at least in some cases, something close. She says that the belief that $\mathrm{P}$ when the evidence favors not-P may be "excusable" even if it is not permissible. McCormick, Believing against the Evidence.

${ }^{54}$ For a discussion of James' conditions, see Aikin, Evidentialism and the Will to Believe.

${ }^{55}$ For a critique of James view, see Aikin. For a non-evidentialist view about how to solve the lining drawing problem, see McCormick, Believing against the Evidence. 
acknowledge that your peers have good non-evidential reasons for holding $\mathrm{Q}$ and $\mathrm{R}$. Of course, the three of you will disagree about which of $\mathrm{P}, \mathrm{Q}$, or $\mathrm{R}$ is true, but the question is what reasons can be offered to adjudicate the issue. By hypothesis, none is justified according to evidentialist standards, so it is not clear that arguing about evidence for or against $\mathrm{P}, \mathrm{Q}$, or $\mathrm{R}$ is even relevant, since by hypothesis all are justified by non-evidentialist standards. ${ }^{56}$

Finally, the reflective nature of at least some philosophical views presents special difficulties. The optimistic batter's belief that he will make the next hit is probably helped by not reflecting too much on the idea that his belief goes against the evidence. For philosophers who accept the Oracle of Delphi's directive to "know thyself", things are not so straightforward. It seems that opting for non-evidentialism will permit one to utter the following sorts of sentences, which have a (neo) Moorean absurdity sound to them: "I hold a Dogmatic belief about P, and the evidence indicates that the belief that $\mathrm{P}$ is probably false". The question for non-evidentialists, then, is whether the explanation that the belief is held for non-evidentialist reasons can dispel the seeming absurdity of such sentences.

In suggesting that these are "obstacles" to a nonevidentialist response to the revision, I do not mean to suggest that they are insurmountable obstacles. As noted, I am not attempting to adjudicate the issue between

${ }^{56}$ Perhaps the non-evidentialist could appeal to something like a threshold account of evidence. For example, one version of this idea might be that merely showing that some contrary view held by a philosophical opponent is likely false is not sufficient to show that doxastic revision is required, but showing that there is evidence that it is certainly wrong is sufficient to show that doxastic revision is required. 
evidentialists and non-evidentialists, so it may be that the costs associated with these obstacles should be borne.

Turning now to evidentialism, the much more popular position in the ethics of belief dispute ${ }^{57}$, we may divide evidentialist responses in terms of whether they offer a collective or individual response to the revision question. The Cruel God analogy already indicates that collectively philosophers would have more true beliefs, and fewer false beliefs, if they adopted the beliefs of Skeptical-Dogmatists. However, as intimated above, such a reaction would require a seismic shift in doxastic attitudes for the average philosopher. Skeptical-Dogmatism appears to be an extremely unpopular position; it does not even appear as an option on Bourget and Chalmers' survey. As noted, there are categories for Dogmatists (accept/lean) and Skeptics (agnostic/undecided) to cast their votes. The closest option for a Skeptical-Dogmatist is "Reject all", but this is too strong, for it does not capture the Skeptical-Dogmatist who would favor a "lean against all" option if it were offered.

Furthermore, when philosophers have reflected on the possibility of something like Pyrrhonian Skepticism about philosophical theories, e.g., as raised in the peer disagreement literature, they have described such a skeptical response in histrionic terms of which Chicken Little would

${ }^{57}$ Andrew Chignell describes evidentialism as "...far and away the dominant ethic of belief among early modern and contemporary philosophers alike." This claim is also made in McCormick, Believing against the Evidence. Mittag, Evidentialism. Internet Encyclopedia of Philosophy.

Manuscrito - Rev. Int. Fil. Campinas, v. 45, n. 2, pp. 1-49, Apr.-Jun. 2022. 
approve: Skepticism is "absurd" 58 , "bad" 59 "worrisome"60, "intuitively false ${ }^{61}$ ", a thing to which many are "averse"62, and "even worse than being false-quite uninteresting". ${ }^{63,64}$ Since Skeptical-Dogmatism constitutes an even darker form of skepticism, one can only image that it would be described in even less flattering terms. As a prediction about how philosophers would react to the accuracy argument, widespread doxastic revision in favor of SkepticalDogmatism is a possible but very improbable reaction. ${ }^{65}$

58 Adam Elga, "Reflection and Disagreement," Nô̂s 41, no. 3 (2007): 478-502.

${ }^{59}$ Sosa, "The Epistemology of Disagreement," 2.

${ }^{60}$ A. Goldman and T. Blanchard, Social Epistemology the Stanford Encyclopedia of Philosophy. Summer 2016 Edition, 2015.

${ }^{61}$ Michael Thune, "Partial Defeaters' and the Epistemology of Disagreement," The Philosophical Quarterly 60, no. 239 (2010): 35572.

${ }^{62}$ David Christensen, "Epistemology of Disagreement: The Good News," The Philosophical Review, 2007, 187-217.

63 David Enoch, "Not Just a Truthometer: Taking Oneself Seriously (but Not Too Seriously) in Cases of Peer Disagreement," Mind, 2010, 953-97.

${ }^{64}$ See (Machuca, 2015), for discussion of various dismissals of skepticism with little or no argument. Some have taken skepticism about philosophy seriously, but they appear to be a tiny minority at present. See, for example, Brian Ribeiro, "Philosophy and Disagreement," Crítica: Revista Hispanoamericana de Filosofia, 2011, 325. Richard Fumerton, "You Can't Trust a Philosopher," in Disagreement (Oxford University Press, 2010). Goldberg, "Reliabilism in Philosophy.") express similar doubts about whether philosophers' beliefs are likely true.

${ }^{65}$ Cf. "Some of the distinctness of ancient skepticism lies in the fact that it is developed by philosophers who genuinely think of 
Of course, there is no mechanism (like the Cruel God's app) for evidentialists to respond collectively to the accuracy argument: individual philosophers cogitating the accuracy argument must think through the consequences for him or herself. Since the accuracy argument works with average accuracy rather than individual accuracy, the argument has no direct consequences for any individual's doxastic attitudes. Suppose, for example, that the accuracy of your philosophical beliefs is far above that of the average philosopher's-perhaps your beliefs are perfectly accurate. Obviously if you were to change your beliefs to that of a Skeptical-Dogmatist, your accuracy would decrease. And if you were to use the Cruel God's app to set other philosophers to believe the same as you, then the Cruel God's challenge would have a happy ending. So, the accuracy argument does not show that setting the app to one's belief is always the wrong strategy. However, since we are considering disputes where there is no simple majority, and at most one Dogmatic view is correct, the argument shows that for most philosophers, setting the app to one's current beliefs is the wrong strategy. Contrariwise, the SkepticalDogmatism strategy always ensures greater than average accuracy (and the survival of humanity). ${ }^{66}$

themselves as skeptics. In later epistemology, skepticism is largely construed from the outside." Katja Vogt, "Ancient Skepticism," in Stanford Encyclopedia of Philosophy, 2010, http://stanford.library.usyd.edu.au/entries/skepticism-ancient/.

${ }^{66}$ Space considerations prohibit engagement with the voluminous literature on peer disagreement. It might be thought that this paper presupposes what has become known as 'Conciliationism': the view that we ought to lower our confidence in light of revelation of disagreement with epistemic peers. Or, to put the point the other way around, it might be thought that the argument here presupposes the falsity of the noble opposition to Conciliationism, 'Steadfast', which says that such disagreement need not require us 
So, if you think your ability to discover philosophical truth is above average, then the accuracy argument does not provide you with reason for belief revision. Contrariwise, if you don't think of yourself as above average in terms of discovering the truth (you think of yourself as average or below average), then the accuracy argument provides evidence for belief revision, that is, you would likely have more true beliefs and fewer false ones if you were to adopt the beliefs of a Skeptical-Dogmatist.

This leaves us with a puzzling situation: If the prediction above that very few philosophers will adopt the beliefs of a Skeptical-Dogmatist is true, then it seems that the vast majority of philosophers must believe that they are above average in terms of determining the truth. ${ }^{67}$ But it is impossible for the vast majority to be above average. As argued above, at most, a minority could be correct. The most plausible answer to this puzzle seems to be that most philosophers believe (or perhaps unreflectively presuppose) they are above average in terms of discovering the truth, when in fact they are not. Here again Socrates ${ }^{68}$ seems relevant. In the Philebus, Socrates describes three ways in which people tend to do the opposite of the famous Delphic inscription "know yourself". The first is that people tend to

to reduce, or at least significantly reduce, our confidence in our views. The sort of Steadfast response canvased in this paragraph provides some evidence of the independence of the argument, since the Steadfaster need not disagree with the conclusions of this paper.

${ }^{67}$ This assumes that the number of non-evidentialists is quite small. If this assumption is false, then the claim here should be rephrased to include just evidentialists.

${ }^{68}$ I make no effort to distinguish Plato and Socrates here. If one thinks that this view is better attributed to Plato, then please read 'Plato' where I have written 'Socrates'. 
think they are richer than they in fact are. The second is that people tend to think they are taller and better looking than they in fact are. The third is as follows:

Socrates: But an overwhelming number are mistaken about the third kind, which belongs to the soul, namely virtue, and believe that they are superior in virtue, although they are not.

Protarchus: Very much so.

Socrates: And, again, among the virtues, is it not especially to wisdom that the largest number of people lay claim, puffing themselves up with quarrels and false pretensions to would-be knowledge?69

We need only substitute "true belief" for what Socrates describes as "false pretensions to would-be knowledge" to describe the possibility that so many philosophers think (or presuppose) they are above average. Socrates famously recommended much more epistemic humility. This explanation suggests that, at least in terms of accuracy of their beliefs, most philosophers would do well to channel, with Ulyssa, a little more of Socrates' spirit, and a little less of Euthyphro's and Ion's epistemic hubris.

To summarize the answers to the revision question: On the one hand, at least some robust forms of nonevidentialism offer a means to avoid the imputation that the accuracy argument offers reasons for belief revision, although there are some obstacles to address in opting for non-evidentialism. On the other hand, if you are an evidentialist, then there are two options. If you do not think you are above average in your ability to determine the truth in philosophical disputes, then the accuracy argument

${ }^{69}$ John M. Cooper and D. S. Hutchinson, Plato Complete Works, 1997. 48e-49a.

Manuscrito - Rev. Int. Fil. Campinas, v. 45, n. 2, pp. 1-49, Apr.-Jun. 2022. 
provides you with reason to revise your beliefs to align with that of Skeptical-Dogmatism. If you think you are above average in your ability to determine philosophical truth, then the accuracy argument does not offer reason for belief revision. ${ }^{70}$

\section{References}

Aikin, S. (2014). Evidentialism and the Will to Believe. Bloomsbury USA.

Ballantyne, N. (2016). Verbal disagreements and philosophical scepticism. Australasian Journal of Philosophy, 94(4), 752-765.

Baumann, M. (2018). Parfit, Convergence, and Underdetermination. J. Ethics \& Soc. Phil., 13, 191.

Bourget, D., \& Chalmers, D. J. (2014). What do philosophers believe? Philosophical Studies, 170(3), 465-500.

Chignell, A. (2018). The Ethics of Belief. In Stanford Encyclopedia of Philosophy. https://plato.stanford.edu/entries/ethics-belief/

Christensen, D. (2007). Epistemology of disagreement: The good news. The Philosophical Review, 187-217.

Clifford, W. K. (2010). The ethics of belief and other essays. Prometheus Books.

Cooper, J. M. (2007). Socrates and Philosophy as a Way of Life. Maieusis: Essays in Ancient Philosophy in Honour of Myles Burnyeat, 20-43.

${ }^{70}$ For much assistance, thanks to Marc Moffett, Jean-Paul Vessel, and two anonymous referees at this journal.

Manuscrito - Rev. Int. Fil. Campinas, v. 45, n. 2, pp. 1-49, Apr.-Jun. 2022. 
, \& Hutchinson, D. S. (1997). Plato complete works. Hackett Publishing.

Dorst, K. (2019). Lockeans maximize expected accuracy. Mind, 128(509), 175-211.

Driver, J. (2014). The History of Utilitarianism. In The Stanford Encyclopedia of Philosopby. https://plato.stanford.edu/archives/win2014/entrie s/utilitarianism-history

Easwaran, K., \& Fitelson, B. (2015). Accuracy, coherence, and evidence. Oxford Studies in Epistemology, 5, 61-96.

Elga, A. (2007). Reflection and disagreement. Nô̂s, 41(3), 478-502.

Enoch, D. (2010). Not just a truthometer: Taking oneself seriously (but not too seriously) in cases of peer disagreement. Mind, 953-997.

Feldman, R. (2003). Epistemology. Pearson College Division.

Friedman, J. (2013). Suspended judgment. Philosophical Studies, 162(2), 165-181.

Fumerton, R. (2010). You Can’t Trust a Philosopher. In Disagreement. Oxford University Press.

Goldberg, S. C. (2009). Reliabilism in philosophy. Philosophical Studies, 142(1), 105-117.

Goldman, A., \& Blanchard, T. (2019). Social Epistemology. In Stanford Encyclopedia of Philosophy. https://plato.stanford.edu/entries/epistemologysocial/

Hankinson, R. J. (1999). The Sceptics. Routledge.

Hazlett, A. (2013). A luxury of the understanding: On the value of true belief. Oxford University Press. 
Hegel, G. W. F. (1991). Hegel: Elements of the philosophy of right. Cambridge University Press.

James, W. (2014). The will to believe. Routledge.

John, D. (1934). Art as experience. New York: Minton, Balch, and Company.

Lewis, D. K. (1983). Philosophical Papers: Volume I. Oxford University Press.

Machuca, D. E. (2011). Ancient Skepticism: Pyrrhonism. Philosophy Compass, 6(4), 246-258.

Masny, M. (2018). Friedman on suspended judgment. Synthese, 1-18.

McCormick, M. S. (2014). Believing against the evidence: Agency and the ethics of belief. Routledge.

Mittag, D. M. (2015). Evidentialism. In Internet Encyclopedia of Philosophy. https://iep.utm.edu/evidenti/

Parfit, D. (1987). Reasons and Persons. Oxford University Press.

Pettigrew, R. (2016a). Accuracy and the Laws of Credence. Oxford University Press.

- (2016b). Jamesian epistemology formalised: An explication of 'The will to believe.' Episteme, 13(3), 253-268.

Rawls, J. (1971). A Theory of Justice. Harvard University Press.

Ribeiro, B. (2011). Philosophy and disagreement. Crítica: Revista Hispanoamericana de Filosofía, 3-25.

Sextus Empiricus. (1996). Outlines of Pyrrhonism. In The Skeptic Way (translated by Benson Mates). Oxford University Press. 
Sosa, E. (2010). The Epistemology of Disagreement. In Social Epistemology (pp. 278-297). Oxford University Press.

Steinberger, F. (2019). Accuracy and epistemic conservatism. Analysis, 79(4), 658-669.

Thorsrud, H. (2009). Ancient Scepticism. University of California Press.

Thune, M. (2010). 'Partial defeaters' and the epistemology of disagreement. The Philosophical Quarterly, 60(239), 355372.

Vogt, K. (2010). Ancient skepticism. In Stanford Encyclopedia of Philosophy. http://stanford.library.usyd.edu.au/entries/skepticis m-ancient/

$(\infty c)$ BY 